\title{
The Effects of Teacher Candidates' Physical Activity Levels on Health-Related Quality of Life
}

\author{
Barış Gürol $^{1}$, Gülsün Güven ${ }^{1} \&$ Dilek Yalız-Solmaz ${ }^{1}$ \\ ${ }^{1}$ Faculty of Sports Sciences, Eskişehir Technical University, Turkey \\ Correspondence: Barış Gürol, Faculty of Sports Sciences, Eskişehir Technical University, Eskisehir, Turkey.
}

Received: August 15, 2019

Accepted: September 21, 2019 Online Published: October 28, 2019

doi:10.5539/ies.v12n11p178

URL: https://doi.org/10.5539/ies.v12n11p178

\begin{abstract}
The aim of this research was to determine the effects of physical activity levels of teacher candidates on the sub-dimensions of health-related quality of life. In the research among the quantitative research methods, relational survey model was used. A total of 90 teacher candidates participated in this research. The International Physical Activity Questionnaire-Short Form (IPAQ-SF) and the 36-Item Short Form Health Survey (SF-36) were used in this study. In the data analysis, "percentage, frequencies, standard deviation, mean, Product-Moment Correlation coefficients and Multiple regression" were used. According to the results, role functioning/emotional, pain and general health sub-dimensions are important predictors on physical activity levels. However, physical functioning, emotional well-being, vitality, social functioning, role functioning/physical, sub-dimensions have not an important impact on physical activity levels statistically. As a conclusion, participation in physical activity can be said to have a negative effect on emotional problems and pain, and a positive effect on general health status.
\end{abstract}

Keywords: physical activity, health related quality of life, teacher candidates, regression

\section{Introduction}

Inactive lifestyle increases the risk of developing many health conditions particularly cardiovascular and coronary heart diseases, diabetes mellitus, risks of certain cancers as colon and breast cancers, hypertension, osteoporosis, poor musculoskeletal and cardiorespiratory fitness, high blood pressure and elevated cholesterol levels, overweight or obesity, anxiety and depression (Cummings et al., 1985; Berlin \& Colditz, 1990; Lee et al., 1991; Arroll \& Beaglehole, 1992; Wannamethee \& Shaper, 1992; Martinez et al., 1997; Uçkun \& Çalıkoğlu, 2003; Bize et al., 2007; Lahti et al., 2010; Li et al. 2016).

Regular moderate intensity physical activity decreases the risk of various chronic diseases as hypertension, coronary heart disease, cardiovascular disease, diabetes, cancer, all-cause mortality and preserves both physical and intellectual health and functions (Saxena et al., 2005; Acree et al., 2006; Blair \& Morris, 2009).

Health-related quality of life (HRQL) can be described as how well his/her perceived wellbeing in intellectual, physical and social domains of health (Brown et al., 2004). The health benefits from physical activity are well-known and research on HRQL in the physical activity domain has predominately been focused on elder populations and among patients with chronic diseases (Elavsky et al., 2005; Acree et al., 2006; Bize et al., 2007; Burke et al., 2017; Pati et al., 2018; Groessl et al., 2019).

While little is known regarding HRQL and its relationship with physical activity level (Bize et al., 2007), it is stated that younger people propose that physical activity level is positively effect to HRQL (Maher et al., 2016).

However, it is not clear whether physical activity increase specific sub-dimensions of HRQL (Acree et al., 2006). The aim of this study was to reveal the effects of teacher candidates' physical activity levels on the sub-dimensions of HRQL.

\section{Methods}

\subsection{Research Model}

In the research among the quantitative research methods, relational survey model was used. The relational survey model is a research design that aims to determine the existence and degree of change between two and more variables together (Karasar, 2007). 


\subsection{Participants}

A total of 110 questionnaires were distributed to teacher candidates from Department of Physical Education and Sports Teacher Training in Eskişehir Technical University and 90 of them were completed and returned, giving an overall response rate of 81.82 percent. The data were gathered during 2018-2019 Academic Year. $42.2 \%$ of the teacher candidates are women and $57.8 \%$ of the teacher candidates are male in this research. The ages differences of the participants are as follow: $42.2 \%$ of them are in $18-20$ years old, $43.3 \%$ of them are in $21-23$ years old and $14.4 \%$ of these teacher candidates are in 24 years old and above.

\subsection{Data Collection Tools}

\subsubsection{The International Physical Activity Questionnaire-Short Form (IPAQ-SF)}

There are various questionnaires to determine the physical activity levels (Lee et al., 2011). It was indicated that IPAQ-SF version is one of the most appropriate and widely used self-report form to assess physical activity levels (Tierney et al., 2015; Lavelle et al., 2019). IPAQ is designed to evaluate the young people/middle-aged adults and special groups' physical activity levels (Craig et al., 2003). The validity and reliability study of the scale, in Turkey in 2005 by Ozturk (2005).

It consists of seven questions to measure average daily time spent walking, sitting and participating in activity of moderate and high intensity and produces a physical activity score based on last seven days (Tierney et al., 2015; Sanda et al., 2017; Lavelle et al., 2019).

Physical activity data from the survey were converted to energy expenditure values predicated as MET scores. The total hours calculated in each physical activity levels were multiplied by the specific MET score for the activity to determine the weekly physical activity level (Hagstromer et al., 2006). Physical activity levels are determined by using MET scores as vigorous intensity physical activity level (8.0 MET), moderate intensity physical activity level (4.0 MET), walking (3.3 MET), sitting (1.5 MET) (Özüdoğru, 2013).

\subsubsection{The 36-Item Short Form Health Survey (SF-36)}

The 36-Item Short Form Health Survey (SF-36) is developed for assessing HRQL (Lins \& Carvalho, 2016). The validity and reliability study of the scale, in Turkey (Koçyiğit et al., 1998).

The SF-36 consisting of 36 items assessing eight sub-dimensions: Physical Function (PF), Social Function (SF), Role Function - Physical (RFP), Role Function - Emotional (RFE), Emotional Well-being (EW), Vitality (VT), Bodily Pain (BP) and General Health Perception (GHP) (Khanna et al., 2010; Burholt \& Nash, 2011; Lins \& Carvalho, 2016; Matcham et al., 2016; İnci et al., 2017; Jacobsen et al., 2018).

SF-36 sub-dimensions are evaluated from 0 to 100 , with a higher score which indicated better health living (Khanna et al., 2010; İnci et al., 2017). Item scores were transformed to $0-100$ point scales $(0=$ worst, $100=$ best $)$ using the SF-36 algorithm (Jacobsen et al., 2018).

\subsection{Data Analysis}

Data obtained through IPAQ short form and HRQL short form-36 (SF-36), and the scores obtained from the assessment were coded and computed using the SPPS 24.0, which was also used to perform analyses. In the data analysis, "percentage, frequencies, standard deviation, mean, Product-Moment Correlation coefficients and Multiple regression" were calculated. To determine the relationship between quality of life behaviors and physical activity levels, correlation coefficients were used. Multiple regression analysis was performed to determine whether the scores are predictive of each other $(\beta)$.

\section{Results}

Table 1. Teacher candidates' physical activity levels

\begin{tabular}{lcc}
\hline & $\mathrm{f}$ & $\%$ \\
\hline Low Intensity Level & 10 & 11.1 \\
Moderate Intensity Level & 31 & 34.4 \\
High Intensity Level & 49 & 54.4 \\
\hline
\end{tabular}

As shown in Table 1, it is find out that $54.4 \%$ of teacher candidates were in high physical activity level while $34.4 \%$ of them were in moderate physical activity level and $11.1 \%$ of them were in low physical activity level. 
Table 2. Teacher candidates' quality of life behaviors

\begin{tabular}{lccc}
\hline & $\mathrm{N}$ & $X$ & $\mathrm{SD}$ \\
\hline $\mathrm{PF}$ & 72 & 89.94 & 14.17 \\
RFP & 72 & 71.67 & 37.70 \\
$\mathrm{RFE}$ & 72 & 57.78 & 42.63 \\
$\mathrm{VT}$ & 72 & 63.94 & 17.00 \\
$\mathrm{EW}$ & 72 & 70.22 & 15.19 \\
$\mathrm{SF}$ & 72 & 65.69 & 25.59 \\
$\mathrm{BP}$ & 72 & 73.69 & 19.37 \\
GHP & 72 & 69.00 & 15.65 \\
\hline
\end{tabular}

The SF-36 consisting of 36 items assessing eight sub-dimensions: Physical Function (PF), Social Function (SF), Role Function - Physical (RFP), Role Function - Emotional (RFE), Emotional Well-being (EW), Vitality (VT), Bodily Pain (BP) and General Health Perception (GHP).

As shown in Table 2, it was examined that the highest score belong to in $\mathrm{PF}(\mathrm{M}=89.94)$ and then $\mathrm{BP}(\mathrm{M}=73.69)$ and RFP (M=71.67) sub-dimensions, the lowest score belong to EW ( $M=70.22)$, GHP (M=69.00), SF ( $M=65.69)$, VT $(\mathrm{M}=63.94)$ and $\mathrm{RFE}(\mathrm{M}=57.78)$ sub-dimensions.

Table 3. Correlations between physical activity levels and quality of life sub-dimensions

\begin{tabular}{|c|c|c|c|c|c|c|c|c|c|c|}
\hline & & 1 & 2 & 3 & 4 & 5 & 6 & 7 & 8 & 9 \\
\hline \multirow{3}{*}{ PF } & $\mathrm{r}$ & 1 & & & & & & & & \\
\hline & $\mathrm{p}$ & & & & & & & & & \\
\hline & $\mathrm{N}$ & 90 & & & & & & & & \\
\hline \multirow{3}{*}{ RFP } & $\mathrm{r}$ & $.391^{* *}$ & 1 & & & & & & & \\
\hline & $\mathrm{p}$ & .000 & & & & & & & & \\
\hline & $\mathrm{N}$ & 90 & 90 & & & & & & & \\
\hline \multirow{3}{*}{ RFE } & $\mathrm{r}$ & .163 & $.488^{* *}$ & 1 & & & & & & \\
\hline & $\mathrm{p}$ & .124 & .000 & & & & & & & \\
\hline & $\mathrm{N}$ & 90 & 90 & 90 & & & & & & \\
\hline \multirow{3}{*}{ VT } & $\mathrm{r}$ & .118 & .095 & -.083 & 1 & & & & & \\
\hline & $\mathrm{p}$ & .270 & .372 & .438 & & & & & & \\
\hline & $\mathrm{N}$ & 90 & 90 & 90 & 90 & & & & & \\
\hline \multirow{3}{*}{ EW } & $r$ & .179 & .141 & -.189 & $.648^{* *}$ & 1 & & & & \\
\hline & $\mathrm{p}$ & .091 & .186 & .402 & .000 & & & & & \\
\hline & $\mathrm{N}$ & 90 & 90 & 90 & 90 & 90 & & & & \\
\hline \multirow{3}{*}{ SF } & $\mathrm{r}$ & .206 & $.397^{* *}$ & $.455^{* *}$ & .126 & .057 & 1 & & & \\
\hline & $\mathrm{p}$ & .052 & .000 & .000 & .238 & .596 & & & & \\
\hline & $\mathrm{N}$ & 90 & 90 & 90 & 90 & 90 & 90 & & & \\
\hline \multirow{3}{*}{ BP } & $\mathrm{r}$ & $.272^{* *}$ & $.402^{* *}$ & .198 & $.222^{*}$ & .196 & $.364^{* *}$ & 1 & & \\
\hline & $\mathrm{p}$ & .009 & .000 & .062 & .035 & .064 & .000 & & & \\
\hline & $\mathrm{N}$ & 90 & 90 & 90 & 90 & 90 & 90 & 90 & & \\
\hline \multirow{3}{*}{ GHP } & $\mathrm{r}$ & $.253^{*}$ & $.223^{*}$ & -.039 & .143 & .179 & .097 & $.275^{* *}$ & 1 & \\
\hline & $\mathrm{p}$ & .016 & .035 & .717 & .180 & .092 & .361 & .009 & & \\
\hline & $\mathrm{N}$ & 90 & 90 & 90 & 90 & 90 & 90 & 90 & 90 & \\
\hline \multirow{3}{*}{ Physical Activity Level } & $\mathrm{r}$ & .043 & -.160 & $-.276^{* *}$ & .073 & .100 & -.175 & $-.214^{*}$ & .140 & 1 \\
\hline & $\mathrm{p}$ & .688 & .131 & .008 & .493 & .347 & .098 & .042 & .189 & \\
\hline & $\mathrm{N}$ & 90 & 90 & 90 & 90 & 90 & 90 & 90 & 90 & 90 \\
\hline
\end{tabular}

${ }^{*} \mathrm{p}<.05 ; * * \mathrm{p}<.01$.

The SF-36 consisting of 36 items assessing eight sub-dimensions: Physical Function (PF), Social Function (SF), Role Function - Physical (RFP), Role Function - Emotional (RFE), Emotional Well-being (EW), Vitality (VT), Bodily Pain (BP) and General Health Perception (GHP).

The analysis of Table 3 demonstrates that there was a significant negative relationship between the physical 
activity and RFE ( $r=-.276, \mathrm{p}=.008), \mathrm{BP}(\mathrm{r}=-.214, \mathrm{p}=.042)$ whereas the study found no significant relationship with other sub-dimensions.

Multiple regression analysis (backward) was performed to determine the factors affecting the physical activity levels of teacher candidates. Purpose of this analysis is to determine the independent variables that explain the highest dependent variable by adding all independent variable which acting on the dependent variable to the model. Firstly, all the independent variables are included in the model and then statistically insignificant variables and variables which decrease the explaining rate are removed from the model one by one. This statistical process continues until getting the highest corrected $\mathrm{R}^{2}$ value. In accordance with these explanations, model of physical activity was stated as dependent variable in Table 4.

Table 4. Regression table for teacher candidates' physical activity to predict their quality of life behaviors

\begin{tabular}{|c|c|c|c|c|c|c|c|c|c|}
\hline & Model & & $\beta$ & $\mathrm{t}$ & $\mathrm{p}$ & $R$ & Adjusted $R^{2}$ & $\mathrm{~F}$ & $\mathrm{p}$ \\
\hline \multirow{39}{*}{ 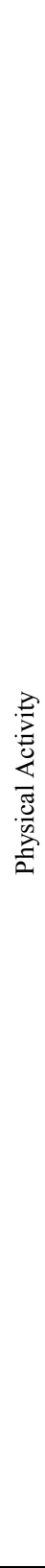 } & \multirow[t]{9}{*}{1} & (Constant) & 2.076 & 3.592 & .001 & .395 & .072 & 1.868 & .076 \\
\hline & & $\mathrm{PF}$ & .005 & .936 & .352 & & & & \\
\hline & & RFP & -.001 & -.373 & .710 & & & & \\
\hline & & RFE & -.003 & -1.506 & .136 & & & & \\
\hline & & VT & .002 & .308 & .759 & & & & \\
\hline & & EW & .003 & .460 & .647 & & & & \\
\hline & & SF & -.001 & -.211 & .834 & & & & \\
\hline & & $\mathrm{BP}$ & -.009 & -2.038 & .045 & & & & \\
\hline & & GHP & .007 & 1.529 & .130 & & & & \\
\hline & \multirow[t]{8}{*}{2} & (Constant) & 2.066 & 3.608 & .001 & .394 & .083 & 2.153 & .047 \\
\hline & & $\mathrm{PF}$ & .005 & .934 & .353 & & & & \\
\hline & & RFP & -.001 & -.400 & .690 & & & & \\
\hline & & RFE & -.003 & -1.687 & .095 & & & & \\
\hline & & VT & .002 & .286 & .775 & & & & \\
\hline & & EW & .003 & .476 & .635 & & & & \\
\hline & & BP & -.009 & -2.152 & .034 & & & & \\
\hline & & GHP & .007 & 1.536 & .128 & & & & \\
\hline & \multirow[t]{7}{*}{3} & (Constant) & 2.081 & 3.672 & .000 & .393 & .093 & 2.527 & .027 \\
\hline & & $\mathrm{PF}$ & .005 & .934 & .353 & & & & \\
\hline & & RFP & -.001 & -.407 & .685 & & & & \\
\hline & & RFE & -.003 & -1.711 & .091 & & & & \\
\hline & & EW & .004 & .837 & .405 & & & & \\
\hline & & $\mathrm{BP}$ & -.009 & -2.145 & .035 & & & & \\
\hline & & GHP & .007 & 1.546 & .126 & & & & \\
\hline & \multirow[t]{6}{*}{4} & (Constant) & 2.145 & 3.959 & .000 & .391 & .102 & 3.029 & .015 \\
\hline & & PF & .005 & .862 & .391 & & & & \\
\hline & & RFE & -.004 & -2.158 & .034 & & & & \\
\hline & & EW & .004 & .806 & .423 & & & & \\
\hline & & $\mathrm{BP}$ & -.009 & -2.326 & .022 & & & & \\
\hline & & GHP & .007 & 1.513 & .134 & & & & \\
\hline & \multirow[t]{5}{*}{5} & (Constant) & 2.316 & 4.652 & .000 & .382 & .106 & 3.639 & .009 \\
\hline & & PF & .005 & .977 & .331 & & & & \\
\hline & & RFE & -.004 & -2.297 & .024 & & & & \\
\hline & & $\mathrm{BP}$ & -.009 & -2.234 & .028 & & & & \\
\hline & & GHP & .008 & 1.597 & .114 & & & & \\
\hline & \multirow[t]{4}{*}{6} & (Constant) & 2.642 & 7.168 & .000 & .370 & .106 & 4.536 & .005 \\
\hline & & RFE & -.004 & -2.184 & .032 & & & & \\
\hline & & BP & -.008 & -2.089 & .040 & & & & \\
\hline & & GHP & .008 & 2.001 & .049 & & & & \\
\hline
\end{tabular}

The SF-36 consisting of 36 items assessing eight sub-dimensions: Physical Function (PF), Social Function (SF), Role Function - Physical (RFP), Role Function - Emotional (RFE), Emotional Well-being (EW), Vitality (VT), 


\section{Bodily Pain (BP) and General Health Perception (GHP).}

As shown in Table 4, SF sub-dimension was removed firstly and then VT, RFP, EW and PF sub-dimensions were removed from the model. Priority of removing the sub-dimension from the model was determined according to low explanation effect on dependent variable. RFE, BP and GHP sub-dimensions explained a large part (11\%) of the total variance in model 6 which has the highest corrected $\mathrm{R}^{2}$ value and also explaining the highest dependent variable $\left(\mathrm{R}^{2}=.106, \mathrm{p}<.05\right)$. According to analysis it was found that $\mathrm{F}=4.536, \mathrm{p}=.005$. According to the results of the analysis on the significance of regression coefficients, RFE, BP and GHP sub-dimensions were found to be significant predictors of physical activity $(\mathrm{p}<.05)$.

\section{Discussion and Conclusions}

Among the teacher candidates, the highest percentage (54.4\%) was students with a high physical activity level, followed by $34.4 \%$ with a moderate physical activity level and $11.1 \%$ with a low physical activity level. According to this finding, it can be said that most of the teacher candidates are physically active people. The main reason for this is that the teacher candidates are students of the Department of Physical Education and Sports Teaching and that practical courses are included in the curriculum. Another reason for the high level of physical activity levels of teacher candidates is that they have opportunities to do physical activities. It is known that the physical activity areas have a significant effect on the participation of people (Honca \& Çetinkaya, 2017; Gümüş \& Ơzgül, 2017). However, when the literature is examined, it contradicts the findings of this study. Yahia, Wang, Rapley, and Dey (2016) reported that physical activity levels and lifestyle score stated that most of the students were not in a active lifestyle. In this research, only $7 \%$ of students indicated having a very active lifestyle. Ölçücü et al. (2015) stated in their research on university students that $36 \%$ of the students were at a sufficient physical activity level, $43 \%$ were at a low physical activity level and $21 \%$ were not physically active. Savc1 et al. (2006) were obtained similar results in their study.

As our research results indicated that the highest means according to HRQL Questionnaire belongs to PF, BP and RFP sub-dimensions and the lowest means belongs to VT and RFE sub-dimensions. Our research results are alike to the research results which examined by Pekmezovic et al. (2011). Pekmezovic et al. (2011) stated that the highest means of the SF-36 scales were obtained for PF sub-dimension and the lowest means for VT sub-dimension.

In the correlation analysis, Pearson correlation coefficients representing the relationship between physical activity levels and HRQL sub-dimensions were calculated. When correlation values between physical activity levels HRQL sub-dimensions are examined, it is observed that there is negatively a significant relationship between physical activity levels and RFE sub-dimension $(\mathrm{r}=.199$; $\mathrm{p}<0.05)$. Also, it has been found out that there is negatively a significant relationship between physical activity levels and BP sub-dimension $(r=-.214 ; \mathrm{p}<0.05)$. It has been determined that there is no significant relationship between physical activity levels and $\mathrm{PF}(\mathrm{r}=.043$; $\mathrm{p}>0.05)$, RFP ( $\mathrm{r}=-.160 ; \mathrm{p}>0.05)$, VT $(\mathrm{r}=.073 ; \mathrm{p}>0.05)$, EW $(\mathrm{r}=.100 ; \mathrm{p}>0.05)$, SF $(\mathrm{r}=.175 ; \mathrm{p}>0.05)$ and GHP sub-dimensions ( $\mathrm{r}=.140 ; \mathrm{p}>0.05)$.

Besides, according to another result of the study, among sub-dimensions of quality of life, only RFE, BP and GHP sub-dimensions could explain $11 \%$ of total variance of physical activity level. This result shows that RFE, BP and GHP sub-dimensions are important predictors on physical activity levels. Other sub-dimensions as PF, VT, RFP, SF, EW sub-dimensions have not an important impact on physical activity level. According to this finding, participation in physical activity can be said to have a negative effect on emotional problems (stress, anxiety, and pain), and a positive effect on general health status.

Most researchers suggest that physical activity had a positive result on quality of life (Gümüş \& Işık, 2018; Hawkins \& Duncan, 1991; Stewart \& King, 1991; Buckelew et al., 1995; Puciato, Borysiuk, \& Rozpara, 2017). Some earlier studies also indicated that there is a positive relationship between physical activity and health (Krzepota, Biernat, \& Florkiewicz, 2015; Quehenberger, Cichocki, \& Krajic, 2014). They may have resulted as physically active people's health status is better than inactive people (Skrzek et al., 2015). Also, researchers have documented the positive effect of physical activity as a factor enhancing the prevention or treatment of anxiety, depression or other neurological disorders (Teychenne, Ball, \& Salmon, 2008; Dziubek et al., 2016; Lancer, Motta, \& Lancer, 2007). For this reason, improving all kinds of infrastructure activities affecting the quality of life of teachers who will train the new generations of the society is important for educating healthy generations.

\section{Limitations}

The current study focused on a limited number of teacher candidates $(\mathrm{n}=90)$ from Department of Physical Education and Sports Teacher Training in Eskişehir Technical University. 


\section{References}

Acree, L. S., Longfors, J., Fjeldstad, A. S., Fjeldstad, C., Schank, B., Nickel, K. J., ... \& Gardner, A. W. (2006). Physical activity is related to quality of life in older adults. Health and quality of life outcomes, 4(1), 37. https://doi.org/10.1186/1477-7525-4-37

Arroll, B., \& Beaglehole, R. (1992). Does physical activity lower blood pressure? A critical review of the clinical trials. Journal of Clinical Epidemiology, 45, 439-447. https://doi.org/10.1016/0895-4356(92)90093-3

Berlin, J. A., \& Colditz, G. A. (1990). A meta-analysis of physical activity in the prevention of coronary heart $\begin{array}{lllll}\text { disease. American } \quad \text { Journal } & \text { Epidemiology, }\end{array}$ https://doi.org/10.1093/oxfordjournals.aje.a115704

Bize, R., Johnson, J. A., \& Plotnikoff, R. C. (2007). Physical activity level and health-related quality of life in the general adult population: A systematic review. Preventive Medicine, 45, 401-415. https://doi.org/10.1016/j.ypmed.2007.07.017

Blair, S. N., \& Morris, J. N. (2009). Healthy Hearts - and the Universal Benefits of Being Physically Active: Physical Activity and Health. Annals of Epidemiology, 19(4), 253-256 https://doi.org/10.1016/j.annepidem.2009.01.019

Brown, D. W., Brown, D. R., Heath, G. W., Balluz, L., Giles, W. H., Ford, E. S., \& Mokdad, A. H. (2004). Associations between physical activity dose and health-related quality of life. Medicine and science in sports and exercise, 36(5), 890-896. https://doi.org/10.1249/01.MSS.0000126778.77049.76

Buckelew, S. P., Murray, S. E., Hewett, J. E., Johnson, J., \& Huyser, B. (1995). Self-efficacy, pain, and physical activity among fibromyalgia subjects. Arthritis Care \& Research, 8(1), 43-50. https://doi.org/10.1002/art.1790080110

Burholt, V., \& Nash, P. (2011). Short Form 36 (SF-36) Health Survey Questionnaire: normative data for Wales. Journal of Public Health, 33(4), 587-603. https://doi.org/10.1093/pubmed/fdr006

Burke, S., Wurz, A., Bradshaw, A., Saunders, S., West, M. A., \& Brunet, J. (2017). Physical Activity and Quality of Life in Cancer Survivors: A Meta-Synthesis of Qualitative Research. Cancers, 9(5), 1-29. https://doi.org/10.3390/cancers9050053

Craig, C. L., Marshall, A. L., Sjostrom, M., Bauman, A. E., Booth, M. L., Ainsworth, B. E., ... Oja, P. (2003). International physical activity questionnaire: 12-country reliability and validity. Medicine and Science in Sports and Exercise, 35, 1381-95. https://doi.org/10.1249/01.MSS.0000078924.61453.FB

Cummings, S. R., Kelsey J. L., Nevitt M. C., \& O’Dowd K. J. (1985). Epidemiology of osteoporosis and $\begin{array}{lllll}\text { osteoporotic } & \text { fractures. } & \text { Epidemiological } & \text { Reviews, } & 7,\end{array}$ https://doi.org/10.1093/oxfordjournals.epirev.a036281

Dziubek, W., Kowalska, J., Kusztal, M., Rogowski, Ł., Gołębiowski, T., Nikifur, M., ... \& Woźniewski, M. (2016). The level of anxiety and depression in dialysis patients undertaking regular physical exercise training-a preliminary study. Kidney and Blood Pressure Research, 41(1), 86-98. https://doi.org/10.1159/000368548

Elavsky, S., McAuley, E., Motl, R. W., Konopack, J. F., Marquez, D. X., Hu, L., ... Diener, E. (2005). Physical activity enhances long-term quality of life in older adults: Efficacy, esteem, and affective influences. Annals of Behavioral Medicine, 30(2), 138-145. https://doi.org/10.1207/s15324796abm3002_6

Farris, M. S., Kopciuk, K. A., Courneya, K. S., McGregor, S. E., Wang, Q., \& Friedenreich, C. M. (2017). Associations of postdiagnosis physical activity and change from prediagnosis physical activity with quality of life in prostate cancer survivors. Cancer Epidemiology and Prevention Biomarkers, 26(2), 179-187. https://doi.org/10.1158/1055-9965.EPI-16-0465

Groessl, E. J., Kaplan, R. M., Rejeski, W. J., Katula, J. A., Glynn, N. W., King, A. C., ... \& Spring, B. (2019). Physical activity and performance impact long-term quality of life in older adults at risk for major mobility disability. American journal of preventive medicine, 56(1), 141-146. https://doi.org/10.1016/j.amepre.2018.09.006

Gümüş, H., \& Işık O. (2018). The Relationship of Physical Activity Level, Leisure Motivation and Quality of Life in Candidate Teachers. International Journal of Progressive Education, 14(5), 22-32. https://doi.org/10.29329/ijpe.2018.157.3

Gümüş, H., \& Özgül, S. A. (2017). Development of Scales for Barriers to Participation and Preference Factors in 
The Use of Recreation Area. Journal of Human Sciences, 14(1), 865-882. https://doi.org/10.14687/jhs.v14i1.4448

Hagströmer, M., Oja, P., \& Sjöström, M. (2006). The International Physical Activity Questionnaire (IPAQ): A study of concurrent and construct validity. Public health nutrition, 9(6), 755-762. https://doi.org/10.1079/PHN2005898

Hawkins, W. E., \& Duncan, T. (1991). Structural equation analysis of an exercise/sleep health practices model on quality of life of elderly persons. Perceptual and motor skills, 72(3), 831-836. https://doi.org/10.2466/pms.1991.72.3.831

Honça, A. A., \& Çetinkaya, T. (2017). Rekreasyonel Faaliyetlere Katılım Engelleri Algısı: Universite Oğrencileri Orneği. International Journal of Recreation and Sports Science, 1(1), 30-37.

İnci, A., Çoban, M., Sarıkaya, M., \& Maden, Ü. (2017). Prediyaliz Kronik Böbrek Hastalarında Kesitsel Bir Çalışma: Yaşam Kalitesi ve Etkileyen Faktörler. Kocatepe Tip Dergisi, 18, 130-135. https://doi.org/10.18229/kocatepetip.368668

Jacobsen, E. L., Bye, A., Aass, N., Fosså, S. D., Grotmol, K. S., Kaasa, S., ... \& Hjermstad, M. J. (2018). Norwegian reference values for the Short-Form Health Survey 36: development over time. Quality of Life Research, 27(5), 1201-1212. https://doi.org/10.1007/s11136-017-1684-4

Khanna, P. P., Ruiz, F. P., Maranian, P., \& Khanna, D. (2010). Long-term therapy for chronic gout results in clinically important improvements in the health related quality of life: Short form-36 is responsive to change in chronic gout. Rheumatology, 50, 740-745. https://doi.org/10.1093/rheumatology/keq346

Koçyiğit, H, Aydemir, Ö., \& Ölmez, N. (1998) Kısa Form-36 (SF-36) nm Türkçe için güvenilirliği ve geçerliliği: Romatizmal hastalığı olan bir grup hasta ile çalışma. 34. Ulusal Psikiyatri Kongresi Bilimsel Çalışma Özet Kitabı. In S. Kültür, \& L. Küey (Eds.), İzmir Güneş Ofset (pp. 290-291).

Krzepota, J., Biernat, E., \& Florkiewicz, B. (2015). The relationship between levels of physical activity and quality of life among students of the university of the third age. Central European journal of public health, 23(4), 335-339. https://doi.org/10.21101/cejph.a4136

Lahti, J., Laaksonen, M., Lahelma, E., \& Rahkonen, O. (2010). SF-36 total score as a single measure of health-related quality of life: Scoping review. Preventive Medicine, 50, 246-250. https://doi.org/10.1016/j.ypmed.2010.02.007

Lancer, R., Motta, R., \& Lancer, D. (2007). The effect of aerobic exercise on obsessive-compulsive disorder, anxiety, and depression: A preliminary investigation. The Behavior Therapist, 30, 53-62.

Lavelle, G., Noorkoiv, M., Theis, N., Korff, T., Kilbride, C., Baltzopoulos, V., ... \& Ryan, J. M. (2019). Validity of the International Physical Activity Questionnaire Short Form (IPAQ-SF) as a measure of physical activity (PA) in young people with cerebral palsy. Physiotherapy. https://doi.org/10.1016/j.physio.2019.08.013

Lee, I., Paffenbarger, R. S., \& Hsieh, C. (1991). Physical activity and risk of developing colorectal cancer among college alumni. Journal of the National Cancer Institute, 83, 1324-1329 https://doi.org/10.1093/jnci/83.18.1324

Lee, P. H., Macfarlane, D. J., Lam, T. H., \& Stewart, S. M. (2011). Validity of the international physical activity questionnaire short form (IPAQ-SF): A systematic review. International Journal of Behavioral Nutrition and Physical Activity, 8, 115. https://doi.org/10.1186/1479-5868-8-115

Li, Y. N., Shapiro, B., Kim, J. C., Zhang, M., Porszasz, J., Bross, R., ... \& Kopple, J. D. (2016). Association between quality of life and anxiety, depression, physical activity and physical performance in maintenance hemodialysis patients. Chronic diseases and translational medicine, 2(2), 110-119. https://doi.org/10.1016/j.cdtm.2016.09.004

Lins, L., \& Carvalho, F. M. (2016). SF-36 total score as a single measure of health-related quality of life: Scoping review. SAGE Open Medicine, 4, 1-12. https://doi.org/10.1177/2050312116671725

Maher, C. A., Toohey, M., \& Ferguson, M. (2016). Physical activity predicts quality of life and happiness in children and adolescents with cerebral palsy. Disability and rehabilitation, 38(9), 865-869. https://doi.org/10.3109/09638288.2015.1066450

Martínez, M. E., Giovannucci, E., Spiegelman, D., Willett, W. C., Hunter, D. J., \& Colditz, G. A. (1997). Leisure-time physical activity, body size, and colon cancer in women. Journal of the National Cancer Institute, 89(13), 948-955. https://doi.org/10.1093/jnci/89.13.948 
Matcham, F., Norton, S., Steer, S., \& Hotopf, M. (2016). Usefulness of the SF-36 Health Survey in screening for depressive and anxiety disorders in rheumatoid arthritis. BMC musculoskeletal disorders, 17(1), 224. https://doi.org/10.1186/s12891-016-1083-y

Ölçücü, B., Vatansever, Ş., Özcan, G., Çelik, A. \& Paktaş, Y. (2015). Üniversite öğrencilerinde fiziksel aktivite düzeyi ile depresyon ve anksiyete ilişkisi. Uluslararası Türk Eğitim Bilimleri Dergisi, 3(4), 294-303.

Öztürk M. (2005). Üniversitede Eğitim-Öğretim Gören Öğrencilerde Uluslararası Fiziksel Aktivite Anketinin Geçerliliği Ve Güvenirliği Ve Fiziksel Aktivite Düzeylerinin Belirlenmesi. Yüksek Lisans Tezi. Hacettepe Üniversitesi Sağlık Bilimleri Enstitüsü.

Özüdoğru, E. (2013). Üniversite personelinin fiziksel aktivite düzeyi ile yaşam kalitesi arasındaki ilişkinin incelenmesi. Yüksek Lisans Tezi. Mehmet Akif Ersoy Üniversitesi Eğitim Bilimleri Enstitüsü, Beden Eğitimi ve Spor Öğretimi Programı. Burdur.

Pati, S., Swain, S., Patel, S. K., Chauhan, A. S., Panda, N., Mahapatra, P., \& Pati, S. (2018). An assessment of health-related quality of life among patients with chronic obstructive pulmonary diseases attending a tertiary care hospital in Bhubaneswar City, India. Journal of Family Medicine and Primary Care, 7(5), 1047-1053. https://doi.org/10.4103/jfmpc.jfmpc_37_18

Pekmezovic, T., Popovic, A., Tepavcevic, D. K., Gazibara, T., \& Paunic, M. (2011). Factors associated with health-related quality of life among Belgrade University students. Quality of life research, 20(3), 391-397. https://doi.org/10.1007/s11136-010-9754-x

Puciato, D., Borysiuk, Z., \& Rozpara, M. (2017). Quality of life and physical activity in an older working-age population. Clinical interventions in aging, 12, 1627-1634. https://doi.org/10.2147/CIA.S144045

Quehenberger, V., Cichocki, M., \& Krajic, K. (2014). Sustainable effects of a low-threshold physical activity intervention on health-related quality of life in residential aged care. Clinical interventions in aging, 9, 1853-1864. https://doi.org/10.2147/CIA.S70359

Sanda, B., Vistad, I., Haakstad, L. A. H., Berntsen, S., Sagedal, L. R., Lohne-Seiler, H., \& Torstveit, M. K. (2017). Reliability and concurrent validity of the International Physical Activity Questionnaire short form among pregnant women. BMC sports science, medicine and rehabilitation, 9(1), 7. https://doi.org/10.1186/s13102-017-0070-4

Savcı, S., Öztürk, M., Arıkan, H., İnal-İnce, D., \& Tokgözoğlu, L. (2006). Üniversite öğrencilerinin fiziksel aktivite düzeyi. Türk Kardiyoloji Arşivi, 34(3), 166-172.

Saxena, S., Van Ommeren, M., Tang, K. C., \& Armstrong, T. P. (2005). Mental health benefits of physical activity. Journal of Mental Health, 14(5), 445-451. https://doi.org/10.1080/09638230500270776

Skrzek, A., Přidalová, M., Sebastjan, A., Harásková, D., Fugiel, J., Ignasiak, Z., ... \& Rozek, K. (2015). Fine motor skills of the hands in Polish and Czech female senior citizens from different backgrounds. Aging clinical and experimental research, 27(4), 491-498. https://doi.org/10.1007/s40520-014-0299-7

Stewart, A. L., \& King, A. C. (1991). Evaluating the efficacy of physical activity for influencing quality-of-life outcomes in older adults. Annals of Behavioral Medicine, 13(3), 108-116.

Teychenne, M., Ball, K., \& Salmon, J. (2008). Physical activity and likelihood of depression in adults: A review. Preventive medicine, 46(5), 397-411. https://doi.org/10.1016/j.ypmed.2008.01.009

Tierney, M., Fraser, A., \& Kennedy, N. (2015). Criterion validity of the International Physical Activity Questionnaire Short Form (IPAQ-SF) for use in patients with rheumatoid arthritis: comparison with the SenseWear Armband. Physiotherapy, 101(2), 193-197. https://doi.org/10.1016/j.physio.2014.07.005

Uçkun, A., \& Çalıkoğlu, A. S. (2003). Çocukluk çağında tip iki diyabet. Sted, 12(5), 174-179.

Wannamethee, G., \& Shaper, A. G. (1992). Physical activity and stroke in British middle-aged men. British Medical Journal, 304, 597-601. https://doi.org/10.1136/bmj.304.6827.597

Yahia, N., Wang, D., Rapley, M., \& Dey, R. (2016). Assessment of weight status, dietary habits and beliefs, physical activity, and nutritional knowledge among university students. Perspectives in Public Health, 136(4), 231-244. https://doi.org/10.1177/1757913915609945 


\section{Copyrights}

Copyright for this article is retained by the author(s), with first publication rights granted to the journal.

This is an open-access article distributed under the terms and conditions of the Creative Commons Attribution license (http://creativecommons.org/licenses/by/4.0/). 